\title{
Preliminary Study of Coral Reef Conditions in Marine Park and Coral Reef Education Centre Plan Area, Seribu Islands National Park, Indonesia
}

\author{
Hermansyah $^{1,2}$, Tatang Mitra Setia ${ }^{1,3}$, Cipto Utomo ${ }^{2,4}$, Alvira Noer Effendi ${ }^{3,4}$, Annastasya Rahma \\ Ramadhani $^{3,4}$, Sabihis ${ }^{1,5}$, Nurdian Sahril ${ }^{1,2}$ \\ ${ }^{1}$ Institute of Conservation and Marine Potential Development, Jl. Pulau Pramuka No.25, Kepulauan Seribu, Jakarta \\ 14530, Indonesia \\ ${ }^{2}$ Smiling Coral Indonesia (Marine Sustanable Ecoturism), Jl. Ikan Clownfish, Kepulauan Seribu, Jakarta 14530, \\ Indonesia \\ ${ }^{3}$ Study Program of Biology, Faculty of Biology, Universitas Nasional, Jl. Sawo Manila, Jakarta 12520, Indonesia \\ ${ }^{4}$ Marine Conservation Club, Faculty of Biology, Universitas Nasional, Jl. Sawo Manila, Jakarta 12520, Indonesia \\ ${ }^{5}$ Taman Nasional Kepulauan Seribu, Jl. Salemba Raya No. 9, Jakarta Pusat 10440, Indonesia \\ *Corresponding author: hermansyah.seribu@gmail.com
}

\section{ABSTRACT}

Marine waters surrounding Child-friendly Integrated Public Spaces (RPTRA) at Tanjung Elang still has the potential for highly productive coral reef resources, thus enabling the development of ecological-based tourism, education and conservation. Despite the potential, the coral reefs in the surrounding of RPTRA Tanjung Elang has suffered damage caused by anthropogenic activities and natural factors. The aim of this research is to assess the initial condition of coral reef at the location of marine park areal and coral reef education center plan, RPTRA Tanjung Elang Waters, Pramuka Island, Seribu Islands National Park, DKI Jakarta, Indonesia. This research used Underwater Photo Transect/UPT method were analyzed using CPCe 4.1. software (Coral Point Count with Excel extension). The results of physico-chemical parameters measurements showed that water quality in RPTRA Tanjung Elang Waters Pramuka Island, is still within tolerance limits for coral life. The percentage of live coral cover was in a bad category with a low value (5.35\%). The most dominant form of coral growth was submassive (CS) with a percentage value $54.46 \%$. Composition of hard coral genusis consists of 3 family, 5 genus, and 100 species. The most dominant of Porites was with submassive and massive growth form. The index value of diversity shows a low category $(0.56)$. The dominance index value showed a medium category (0.75). Uniformity and mortality index value showed a low category $(0.35$ and 0.43$)$.

Keywords : Coral Reef, Diversity, Ecosystem-Based Marine Park Areal, Seribu Islands, Underwater Photo Transect (UPT)

\section{ABSTRAK}

Perairan laut di sekitar Ruang Publik Terpadu Ramah Anak (RPTRA) Tanjung Elang Pulau Pramuka memiliki potensi sumber daya terumbu karang yang produktif, sehingga masih berpotensi besar untuk pengembangan ekowisata bahari berbasis edukasi, konservasi, dan ekologi. Saat ini terumbu karang di perairan laut RPTRA Tanjung Elang telah mengalami kerusakan akibat dari aktivitas manusia dan faktor alam, sehingga perlu adanya langkah yang komprehensif dengan membuat konsep perbaikan kerusakan ekosistem dengan melakukan kegiatan rehabilitasi dan restorasi terumbu karang yang telah mengalami kerusakan. Penelitian ini bertujuan untuk menilai kondisi awal terumbu karang di lokasi perencanaan 
pembuatan areal taman laut berbasis ekosistem dan Coral Reef Education Center di perairan RPTRA Tanjung Elang Pulau Pramuka. Metode yang digunakan pada penelitian ini adalah metode Underwater Photo Transect/UPT yang kemudian dianalisis menggunakan perangkat lunak CPCe 4.1 (Coral Point Count with Excel extension). Hasil pengukuran fisika kimia perairan menyimpulkan kualitas perairan di RPTRA Tanjung Elang Pulau Pramuka masih dalam batas toleransi untuk kehidupan karang. Hasil analisis persentase tutupan karang hidup masuk dalam kategori buruk dengan nilai persentase 5,35\%. Komposisi bentuk pertumbuhan karang didominasi oleh bentuk submassive dengan nilai persentase 54,46\%. Komposisi marga karang yang ditemukan sebanyak 3 suku, 5 marga, dan 100 individu. Marga karang yang paling banyak ditemukan adalah Porites dengan bentuk pertumbuhan submassive dan massive. Indeks keanekargaman marga karang menunjukkan bahwa di lokasi pengamatan memiliki nilai indeks keanekaragaman rendah yaitu sebesar 0,56. Nilai indeks dominansi sebesar 0,84 dan termasuk dalam kategori sedang. Nilai indeks keseragaman dan indeks kematian karang termasuk dalam kategori rendah yaitu sebesar 0,35 dan 0,43 .

Kata kunci : Areal Taman Laut Berbasis Ekosistem, Diversitas, Kepulauan Seribu, Terumbu Karang, Underwater Photo Transect

\section{INTRODUCTION}

Coral is one of the most important components of coral reef and reef ecosystem. Coral is a general term used to describe the biodiversity of the phylum Coelenterata that most of the group is forming a reef. Meanwhile, reef is a skeleton of limestone structures which is formed by coral animals, algae or other photosynthesize marine organisms. The corals that build reefs are known as scleractinia or stony corals or hard corals are animals whose capable to produce calcium carbonate $\left(\mathrm{CaCO}_{3}\right)$ and almost entirely associated with zooxanthellae [1,2,3]. According to Suharsono, corals are a group of organisms that has a simple nervous system, muscle tissue and reproduction, which has evolved and functioned properly [4]. Similar with other animals, corals has the ability to reproduce asexually or sexually [3]. Asexual reproduction is done by forming polyp buds that will become new individual on the parent polyp, and while budding is a mechanism to increase colony size, it is not a mechanish to form new colonies [5].

Marine waters surrounding Child-friendly Integrated Public Spaces (RPTRA) at Tanjung Elang still has the potential for highly productive coral reef resources. Thus, it will enable the development of ecological-based tourism, education, and conservation. Therefore, it needs to be managed sustainably, considering that coral reefs provide many benefits ecologically, economically, and physically. Coral reefs ecologically beneficial by providing habitat for aquatic flora and fauna, spawning, nursery, refuge, and feeding areas. Moreover, coral reefs can also economically beneficial to human by providing a source of life, food sources (marine fisheries), medicinal resources, marine tourism industry, and as an object of research and education. Furthermore, the physical benefits of coral reefs act as a barrier to waves, currents, and coastal abrasion [6].

Currently, despite the potentials in supporting productive coral resources, the coral reefs of surrounding RPTRA Tanjung Elang has suffered damages caused by several factors. Overfishing with destructive fishing gear (Muro Ami fishing/net compressor), coral and sand mining, destructive marine tourism activities, habitat degradation, impact of coastal development (docks, embankments, fairways, pool port, etc.), poor water environments due to sedimentation and waste pollution (chemical, plastic waste, eutrophication), and also global climate change leads to significant threat to this important ecosystem are the factor which caused damaged of coral reef. The damage in coral reefs that occur continuously, can leads negative impact on the ecological, economic 
and physical in the waters of the Tanjung Elang RPTRA.

According Ilmi MB, using Underwater Photo Transect (UPT) method, the conditions of coral reef in Pramuka Island dock waters was found to be in bad conditions with coral cover percentage value of only $12 \%$ [7]. The most dominant substrate cover was found to be abiotic substrate consisting of rubble, sand, and rock.

Supriharyono indicated that $85 \%$ coral reef in Seribu Islands Waters has suffered damage [8]. The condition of coral reefs in these waters is generally categorized as poor to fair conditions. According to Regional Environment Management Agency (BPLHD) of DKI Jakarta Province [9], 50\% of coral reefs in Seribu Islands Waters consist of rubble, dead corals, and sand. A study from Indonesian Coral Reefs Foundation indicated that coral reef condition in Seribu Islands has fair condition and long-term observation reports showed that percentage of hard coral cover fluctuated from $31.45 \%$ in 2005 , decreased to $28.86 \%$ in 2007 , then increased to $34.27 \%$ in 2009 [10].

The aim of this research is to assess the initial condition of coral reef at the location of marine park areal and coral reef education center plan, RPTRA Tanjung Elang Waters, Pramuka Island, Seribu Islands National Park, DKI Jakarta. This marine park areal, are designated as a marine research activities site, marine cultivation development, sustainable marine ecotourism area, education, and conservation area.

This research is expected to be the beginning step to take further comprehensive steps by conceptualizing the repair of damage to ecosystems through physical rehabilitation and recovery of damaged coral reefs.

Preliminary data of this research are expected to help in providing inputs for buildings of a marine park areal and coral reef education center. Thus, it can provide solutions to recovery coral reef ecosystem that have suffered damage.

\section{METHODS}

Data collection activities and installation of permanent transects was conducted on
November $16^{\text {th }}-17^{\text {th }}, 2019$ in RPTRA Tanjung Elang Waters, Pramuka Island, Seribu Islands National Park, DKI Jakarta, Indonesia. The location were determined according on consideration of unique ecological criteria, own specific use of resources (tourism and fisheries), convenient and easily monitored access.

This research used Underwater Photo Transect/UPT method to assess the condition of coral reef. There was one research stations at a depth of $3 \mathrm{~m}$ and length transect of $20 \mathrm{~m}$ with 3 repetitions (10 $\mathrm{m}$ interval between transects). A frame size $58 \times 44 \mathrm{~cm}$ is placed on the transect line starting from the point $1 \mathrm{~m}$ and each subsequent meter. The frame is placed zig-zag, where the first point is placed near the land, then at the next point, the frame is placed further away from the land (Fig.1). Pictures were taken with a digital camera along each transect line by maintaining a constant vertical distance $( \pm 60$ $\mathrm{cm}$ ) from the frame and the substrate. There were 20 photographs were taken for each transect line, and thus a total of 60 digital photographs were collected on the observation station [11].

All photographs were analyzed using CPCe 4.1 software (Coral Point Count with Excel extension) developed by the National Coral Reef Institute (NCRI) [12]. Results of data analysis are frequency of presence and percentage of lifeform/category. Lifeform/ category used in CPCe has been modified from its initial default to a category that corresponds to the LIT category based on English et al. [13].

\section{Research Location}

Preliminary study of coral reef condition was located in the waters of Tanjung Elang RPTRA Pramuka Island on 16-17 November 2019 (Fig. 2).

Table 1. The Coordinate of Observation

\begin{tabular}{lll}
\hline \multirow{2}{*}{ Start Point } & S & $5^{\circ} 44^{\circ} 46.51^{\prime \prime}$ \\
\cline { 2 - 3 } & E & $106^{\circ} 36^{\circ} 41.96^{\prime \prime}$ \\
\hline \multirow{2}{*}{ Finish Point } & S & $5^{\circ} 44^{\circ} 49.21^{\prime \prime}$ \\
\cline { 2 - 3 } & E & $106^{\circ} 36^{\circ} 40.61^{\prime \prime}$ \\
\hline
\end{tabular}




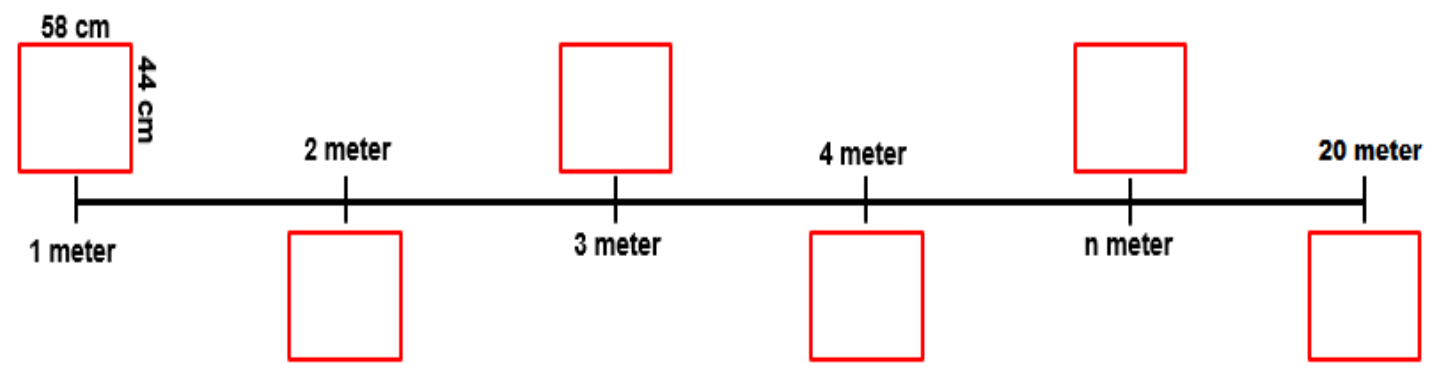

Figure 1. Frame Position on the Transect Line

Location coordinates of observation in this research was recorded using Global Positioning System (GPS). Each area had been determined, then recorded its geographical location with GPS (Table 1).

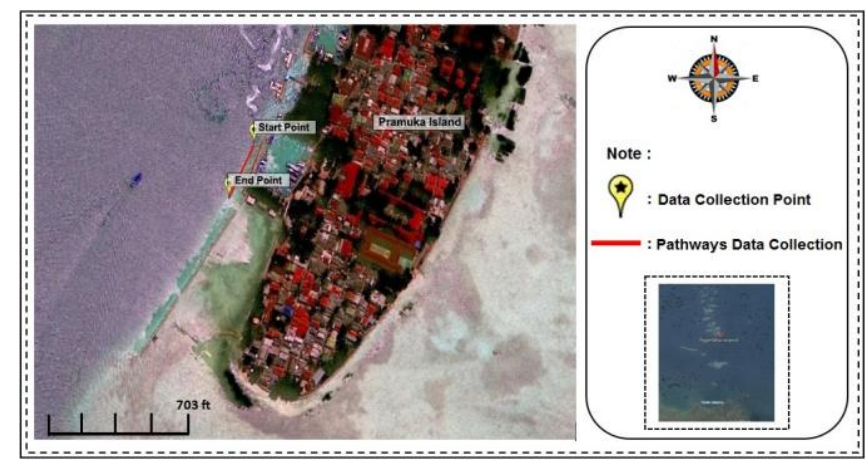

Figure 2. Research Location Map

\section{RESULTS AND DISCUSSIONS}

\section{The Water Quality}

The measurement physico-chemical parameters results are shown in Table 2 . According on the results, water quality in RPTRA Tanjung Elang Waters Pramuka Island, is still within tolerance limits for coral life.

The optimal temperature for coral growth is in the ranges of $25-30^{\circ} \mathrm{C}$ [14]. According to Nybakken [15], the maximum temperature which can be tolerated by coral reefs is around $36-40^{\circ} \mathrm{C}$, whereas minimum temperature is $20^{\circ} \mathrm{C}$.

According The Minister of Environment Decree No.51/2004 (Sea Water Quality) of 2004 , the ideal $\mathrm{pH}$ in waters that can be tolerated by marine biota is in the range of 7-8.5, and water transparency is more than 5 meters.
Table 2.The Water Quality (physico-chemical parameters)

\begin{tabular}{ccc}
\hline $\begin{array}{c}\text { Water } \\
\text { Temperature } \\
\left({ }^{\circ} \mathrm{C}\right)\end{array}$ & $\mathrm{pH}$ & $\begin{array}{c}\text { Water } \\
\text { Transparency } \\
(\mathrm{m})\end{array}$ \\
\hline 30 & 8 & 8 \\
\hline
\end{tabular}

\section{Condition of Live Coral Cover}

The results of the data analysis showed that the percentage of live coral cover at research location was in a bad category with a low value $(5.35 \%)$, in contrast the percentage of abiotic was in good category with a high value (79.31\%) (Fig.3).

The most common abiotics found were rocks, sands, and coral rubbles. High level of abiotic value at this location indicates that coral damage has occurred. The occurred coral damage is thought to be caused by antropogenic activities and natural factors such as strong waves and currents (affected by west-monsoon with high waves and currents).

According to observations, rubbles are generally caused by human physical activities, such as construction of docks, embankments, fairways, pool port, and ship activities. Rubble has an impact due to decreased of a small coral or recruitment. Rubble and rock fractures can be used for the recruitment of corals substrates for the formation of new colonies, but rubble are easy to be moved or unstable, so that recruitment corals cannot survive sticking to the rubble and die, especially in the occurrence of strong water flow. This is reinforced by the statement of Razak [16], that rubble and sand are unstable substrates, because it is easily 
reversed (shifting) by currents and waves, thus making coral reefs difficult to stick.

The percentage value of the other biotic covered in the location was $7.67 \%$. Other type of biota mostly found in the location was the type of sea urchin, Diadema sitosum. According to Nystrom et al. [17], sea urchin is one of the keystone species for the coral reef community. Sea urchins is one of the controllers of microalgae populations in coral reef ecosystems. Water, which is rich of nutrients, will increase the abundance of sea urchins and algae such as plankton and benthic. Benthic algae are the main food for starfish and sea urchins, therefore sea urchins play an important role for eating the benthic algae in the process of attaching coral larvae $[18,19]$.

The percentage value of macroalgae covered in the location was $7.67 \%$. Padina sp. was the macroalgae which was mostly founded. Macroalgae play an important role as a bioindicator of waters quality and become coral competition in coral reef ecosystem [20]. The high algal cover is due to increased water fertility which can be triggered by the entry of nutrients from 13 rivers that flow into Jakarta Bay which will be brought to the Seribu Islands waters and is sourced from household liquid waste pollution on the mainland of Pramuka Island. Another factor that can also contribute to an increase in algae is a reduction of alga predators numbers, such as herbivorous fish. Jompa and McCook [21] stated that all types of macroalgae groups are coral competitors which can threaten the corals live existence if the growth of the alga group is not controlled. Concern about algae growth is a matter that needs special attention. In Caribbean waters, Veirmeij et al. [22] found that algae turf changed the substrate from coral cover to algae cover due to increased nutrition. Herbivorous fish cannot even control the algae turf population. As a result, algae turf is now the main benthic organism in Caribbean waters [23].

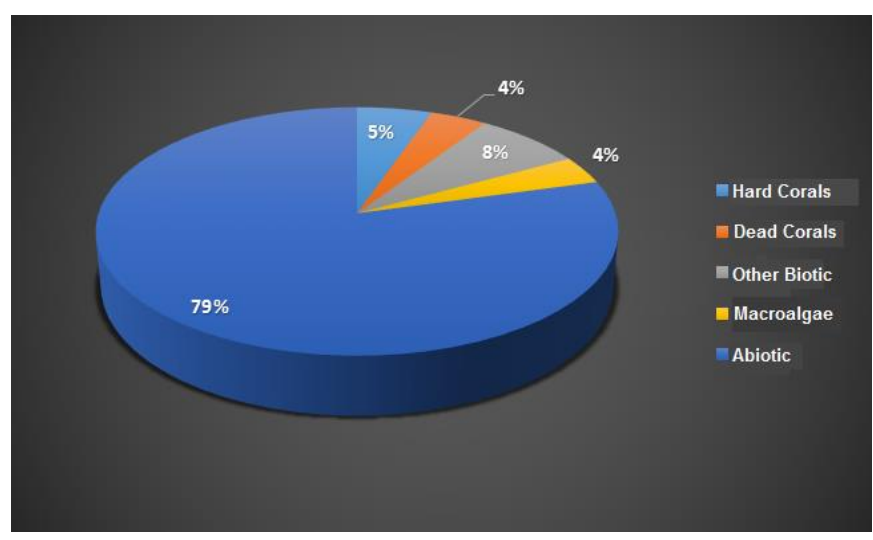

Figure 3. Condition of Coral Cover

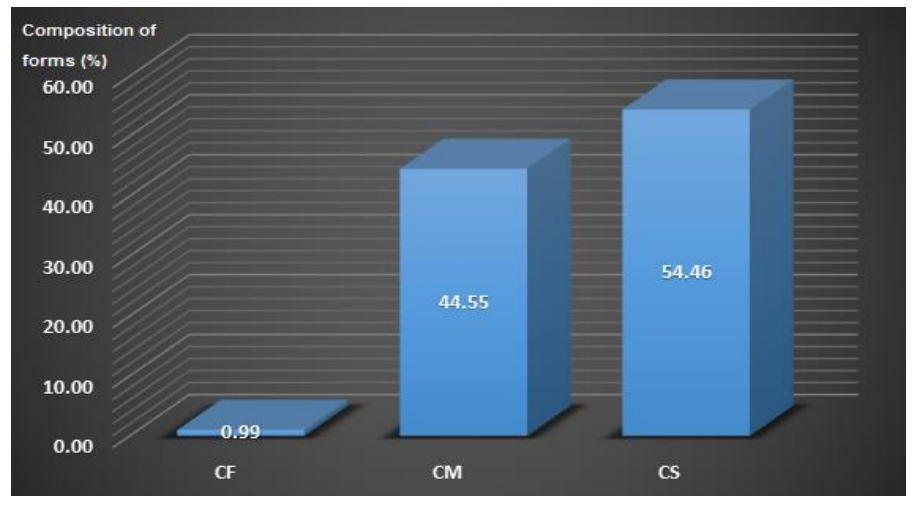

Figure 4. Composition of Coral Growth Forms 


\section{Composition of growth coral forms}

Coral growth forms is one way for corals to adapt in their environmental. The most dominant form of coral growth at research location was submassive (CS) with a percentage value $54.46 \%$, followed by a form of brain coral growth (massive/CM) with a percentage value $44.55 \%$ and the least found was the form coral foliose (CF) growth of $0.99 \%$ (Fig. 4). The high growth form of submassive and massive is due to the type of coral growth that is able to adapt to poor environmental conditions. The condition of the waters in the location has a high level of sedimentation and bad environmental stress due to influences by the west monsoon and human activity such as damages and pollutes.

According to English et al. [24], type of coral which dominated in a habitat is depend from the environmental or condition where that coral is lived. In a habitat, type of coral which is lived can be dominated by particular coral. In the flat area, reef is usually dominated by little corals which commonly massive and submasssive. In the slope area, reef is usually grown by branching corals.

\section{Composition of Hard Coral Genus}

The result of hard coral analysis and identifiation in the location is consists of 3 family, 5 genus, and 100 individuals. Each genus give contriution, Porites give contribution of $86 \%$ which is a dominated genus, followed by Favia 7\%, Goniastrea 1\%, and others genus (Favites and Pavona) 1\% (Table 3).

Table 3. Composition of Hard Coral Genus

\begin{tabular}{ccc}
\hline Family & Genus & $\begin{array}{c}\text { Number of } \\
\text { Species }\end{array}$ \\
\hline \multirow{3}{*}{ Faviidae } & Favia & 7 \\
\cline { 2 - 3 } & Favites & 1 \\
\cline { 2 - 3 } Agariciidae & Goniastrea & 5 \\
\hline Poritidae & Porona & 1 \\
\hline \multicolumn{2}{c}{ Total of individuals } & 86 \\
\hline
\end{tabular}

The most dominant of Porites with submassive and massive growth form is because it capable to adapt in adverse environmental condition. Porites have a high potency to adapt, tolerant of raising temperature, and relative endurance to high turbidity or sedimentation in the waters. Moreover, Porites able to cleanse itself from the depositions which covers the body because produce a lot of mucus. Porites have a high potential of compete, with a long lifespan, have a limit spread ability, and slow growth velocity. Porites in the waters of coral reef also become a bioindicator of waters quality. Porites capable to live and grow in coral reef waters which already polluted and sedimentated.

Porites are capable to adapt in turbid waters environment by metabolism, so at turbid conditions and low salinity waters, Porites mostly become the dominated genus [25]. According to Cappell [26], forms of coral colonies with high levels of sedimentation will tend to be massive, branching, and foliose.

\section{Community Structure of Hard Coral}

To see the condition of coral reef ecology, an integrated analysis is needed which not only based on the amount of reef biota closure, but also explain the relationship between the conditions of coral biota and directly determines the type of ecosystem stability.

\section{Diversity Index (H')}

Index of divesity is used to measure the abundance of communities which based on the number of genus in a location. As the genus grows, the coral community is diversely increased. The index also indicates that as the genus grows, the role of these genus in the community is increase.

The index value of diversity in the location shows a low category which is proved by diversity index value 0.56 . The amount of coral number is affected by destructive activity of human and natural factors such as wave, high sedimentation and pollution. Additionally, the high amount of substrate types such as sand and coral rubble can cause substrate to be unstable for young coral life and the number of corals genus found is low. 


\section{Dominance Index (D)}

The dominance index value from the data analysis shows a medium category with a dominance index value 0.75 . This shows that there are coral clans that dominate.

The dominant genus of hard coral genus is Porites. The high degree of dominance is caused by the Porites able to adapt adverse environmental conditions and has the form of massive and submassive growth which is stronger for encounter environmental pressure. The high degree of dominance of one species in waters indicates the condition of the location is under pressure. If the dominance index value is high, then the diversity index value will be low, which is indicated the dominance of one type over the other types. The amount of domination will direct the condition of the community to be unstable or depressed.

\section{Uniformity Index (E)}

Uniformity index value in the location shows a low category with an uniformity index value 0.35 . This shows that the distribution of the number of individuals in the genus is not the same so there is a tendency for one genus to dominate. The low value of uniformity is due to the dominated genus, the Porites. With decreased waters quality condition because of high pollution, sedimentation, and high pressure damage by human activities, the Porites still be able to survive and adapt.

\section{Mortality (Mi)}

The mortality index value in the location shows a low category with a coral mortality index value 0.43 . Although the number of genus and individual corals found was low, most of the corals found were still alive and turned into yound and small coral colony. If the waters condition turn to be better and can support the growth of coral colonies, then the coral colonies will grow better. This is the cause of the low coral mortality index value at the observation site.

\section{CONCLUSIONS}

1. The study has that the percentage of coral cover in Tanjung Elang RPTRA waters of Pramuka Island was $5.35 \%$ which was included in the bad category.

2. The composition of coral growth forms was dominated by submassive with a percentage value $54.46 \%$.

3. The number of corals found was 3 family, 5 genus, and 100 species which was dominated by the Porites genus in the form of submassive and massive growth.

4. The value of diversity Index, uniformity index, and mortality index were in the low category, sequently; $0.56 ; 0.35$; and 0.43 .

5. The value of dominance index was 0.84 and included in the medium category.

6. The waters of the RPTRA Tanjung Elang Pramuka Island, Seribu Islands National Park, DKI Jakarta, are highly recommended for coral reef ecosystem restoration (remediation) programs through physical rehabilitation and restoration activities (planting coral transplants with some artificial media) which is that will become a marine park area based on ecosystem and coral reef education center.

\section{ACKNOWLEDGMENT}

This research was supported by:

1. Institute of Conservation and Marine Potential Development (LKP2K)

2. Taman Nasional Laut Kepulauan Seribu Office (TNKpS)

3. Management Section of Pramuka Island Region III National Park

4. Seribu Island Regency Administration District

5. Urban Village of Panggang Island

6. Kelompok Perhimpunan Nelayan Ikan Hias dan Tanaman Hias (PERNITAS)

7. Smiling Coral Indonesia (Marine Sustanable Ecoturism)

8. Faculty of Biology, Nasional University, Jakarta

9. Marine Conservation Club, Faculty of Biology, Nasional University (MCC UNAS) 
10. Mitsubishi Electric Group Indonesia.

For all participation and assistance in the field and writing so that this report can be completed properly.

\section{REFERENCES}

[1] Spalding M, Ravilious C, Green E, et al. World Atlas of Coral Reefs. UNEPWCMC. University of California Press. USA. 2001; 424 pages.

[2] Veron J. Corals of Australia and IndoPacific. Angus \& Robertson Publishers. 2000. Australia.

[3] Birkeland C. Lifeand Death of Coral Reefs. Chapman dan Hall. 1997. New York.

[4] Suharsono. Jenis-jenis Karang di Indonesia. Pusat Penelitian OseanografiLIPI. Jakarta. 2008; 344 halaman

[5] Nybakken J. Biologi Laut. Suatu Pendekatan Ekologis. Gramedia. Jakarta. 1998. 458 pages.

[6] Ikawati, Y, Hanggarawati P, Parlan H, et al. 2001. Terumbu Karang di Indonesia. Masyarakat Penulis Ilmu Pengetahuan dan Teknologi, Jakarta: 198 hal.

[7] Ilmi MB. Komposisi Keanekaragaman Karang Keras Di Pulau Pramuka Dan Kotok Besar, Taman Nasiona Laut Kepulauan Seribu, DKI Jakarta Dengan Menggunakan Metode Transek Foto Bawah Air. 2017. Fakultas Biologi Universitas Nasional. Jakarta.

[8] Supriharyono. Pelestarian dan Pengelolaan Sumber Daya Alam di Wilayah Pesisir Tropis. PT Gramedia Pustaka Utama. 2000. Jakarta.

[9] BPLHD. Laporan Status Lingkungan Hidup Daerah Provinsi Daerah Khusus Ibukota Jakarta Tahun 2012. Pemerintah Daerah Khusus Ibukota Jakarta. Badan Pengelola Lingkungan Hidup Daerah. Jakarta. 2013.

[10] Setyawan E, Yusri S, Syahrir M, et al. Terumbu Karang Jakarta: Pengamatan Jangka Panjang Terumbu Karang KepulauanSeribu (2005-2009). Yayasan TERANGI. Jakarta. 2011; 101pages.

[11] Giyanto. Kajian tentang panjang transek dan jarak antar pemotretan pada penggunaan metode transek foto bawah air. Oseanologi dan Limnologi di Indonesia. 2012a; 38 (1): 1-18.
[12] Kohler KE, Gill M. Coral Point Count with Excel extensions (CPCe): a visual basic program for the determination of coral and substrate coverage using random point count methodology. Comput Geosci. 2006; 32(9): 1259-1269.

[13] English S, Wilkinson C, Baker V. Survey Manual for Tropical Marine Resources. Australian Institute of Marine Science. 1997. Edisi kedua. Australia.

[14] Sukirno S. Pengantar Teori Mikroekonomi. Raja Grafindo Persada. 1994. Jakarta.

[15] Nybakken J. Biologi Laut, Suatu Pendekatan Ekologis. 1992. PT Gramedia Pustaka, Jakarta.

[16] RazakT. Hard coral \& reef fish community on the EcoReefs rehabilitation site, Manado Tua Island, Bunaken National Park, North Sulawesi, Indonesia. A monitoring report, Indonesia. 2006; 35 pages.

[17] Nystrom M, Folke C, Moberg F. Coral Reef Disturbance and Resilience in A Human-Dominated Enviroment. Trends in Ecology and Evolution. 2000.

[18] Collin PL, Arnesson C. Tropical Pacific Invertebrates. Coral Reef Press. 1995; California: 290 pages.

[19] Edmunds PJ, Carpenter RC. Recovery of Diadema antillarum reduces macroalga cover and increases abundance of juvenile corals on a Caribbean reef. PNAS. 2001; 98: 5067-5071.

[20] McCook. L. J., Jompa, J., \& Diaz-Pulido, G. (2001). Competition between coral and algae on coral reef: a review of evidence and mechanism. Coral Reefs, 19(4), 400417.

[21] Jompa J, Mc Cook LJ. Coral-Alga Competition: Macroalga with Different Properties Have Different Effect on Coral. Departement of Marine Biology.James Cook University. Townsville, Queensland. Australia. Marine Ecology Progress Series. 2003; 258: 87-95.

[22] Veirmeij MJA, Van Moorselaar I, Engelhard C, et al. The Effects of Nutrient Enrichment and Herbivore Abundance on the Ability of Turf Algae to Overgrow coral in the Caribbean. Plos ONE. 2010.

[23] Gardner T, Coté Gill JA, Grant A, Watkinson AR. Longterm region-wide declines in Caribbean corals. Science. 2003;301:958-960. 
[24] English S, Wilkinson C, Baker V. Manual for Tropical Marine Resources. ASEANAustralian Marine Science Project Living Coastal Resources. 1994. Australia.

[25] De Meesters A, Gomez B, Okamura, et al. The Monopolization Hypothesis and the dispersal-gene flow paradox in aquatic organism. Acta Oecologica-International Journal of Ecology. 2002; 23: 121-135.

[26] Chappell J. Coral Morphology Diversity and Reef Growth. Nature. 1980; 286: 249252. 